\title{
APPLICATION OF SELECTED METHODS FOR EFFECTIVENESS EVALUATION ON THE EXAMPLE OF MODERNIZATION OF ST44 DIESEL LOCOMOTIVE
}

\begin{abstract}
The paper presents the effectiveness evaluation of modernization of the ST44 diesel locomotive based on the analysis of the Life Cycle Cost Analysis and the Cost-Benefit Analysis. The analysis was aimed at identifying measurable economic effects obtained thanks to the modernization of the locomotive in the 25-year period of operation.
\end{abstract}

Keywords: effectiveness assessment, LCC analysis, cost-benefit analysis, rail transport

\section{Introduction}

Among the undertakings aimed at increasing the efficiency of railway transport, activities in the scope of reducing the costs of exploitation and maintenance of traction vehicles play an important role. A way to achieve this goal is the modernization of diesel locomotives, taking into account the conditions of exhaust and noise emissions. The modernization of a railway vehicle should be understood as modification works that change the purpose of the vehicle or improve its overall technical performance, in particular: change of traction characteristics, maximum speed, power, ability to power in different systems ${ }^{1}$. Most often rolling stock mod-

1 Announcement of the Minister of Infrastructure and Construction of 27 January 2016. regarding the publication of a uniform text of the Regulation of the Minister of Infrastructure on general technical conditions for the operation of railway vehicles (Journal of Laws of 2016, item 226, as amended). 
ernization is made for economic or technical reasons. The following are the main goals of modernizing railway transport means ${ }^{2}$ :

- improvement of operational efficiency through reduction of energy or fuel consumption;

- increase in the safety of use;

- increasing inter-repairs;

- increasing technical readiness;

- adjusting technical parameters to the requirements of international regulations;

- reducing negative impact on the natural environment in the field of noise, vibrations and emission of toxic components to the atmosphere;

- improving the working conditions of the driver (ergonomics);

- increase of service comfort indicators.

The subject of the article is the evaluation of the effectiveness of modernization of the ST44 series diesel locomotive. This assessment was the subject of research carried out at the Institute of Rail Vehicles of the Cracow University of Technol$\mathrm{ogy}^{3}$. In order to carry out the effectiveness assessment, the life-cycle cost analysis and cost-benefit analysis were applied.

\section{Variants to be analyzed}

Two variants were adopted in the analysis of the modernization efficiency of the ST44 locomotive:

- ST44 (14D40): an unmodified ST44 locomotive with a 14D40 engine;

- ST44 (GE): a modernized ST44 locomotive based on the integrated General Electric power unit with $2163 \mathrm{~kW}(2900 \mathrm{hp})$.

These variants have been described in detail in scientific studies ${ }^{4}$ prepared by the Institute of Rail Vehicles of the Cracow University of Technology on behalf of a railway carrier in the years 2007-2017. The analyzed variant of the ST44 locomotive modernization concerns the concept proposed by NEWAG S.A., made on the basis of General Electric technology. Modernization in this solution involves the use of an integrated power unit (the so-called "Power Skid"), which includes: an internal combustion engine, generator, air compressor, cooling system and control system. The chassis and bogies are built on the basis of the construction of an old locomotive. The scope of modernization works also includes the modernization of the original traction motors, which are refined on the basis of GE materials

A. Tułecki, Ekonomiczno-techniczne aspekty odnowy parku spalinowych pojazdów trakcyjnych, Czasopismo Techniczne 2005, 3-M.

3 Strategy of renewal of the locomotive park in the enterprise of PKP LHS Sp. z o. o. Paper No. M8/599/2007, Cracow University of Technology, Institute of Rail Vehicles, November 2007; Announcement of the Minister of Infrastructure and Construction of 27 January 2016, regarding the publication of a uniform text of the Regulation of the Minister of Infrastructure on general technical conditions for the operation of railway vehicles (Journal of Laws of 2016, item 226); Evaluation of the modernization efficiency of ST44 series locomotives based on current operational data. Paper No. M-8/14/2010/6, Cracow University of Technology Institute of Rail Vehicles, Krakow, May 2010.

4 Ibidem. 
and technology. The proposed type of modernization relies on replacing all the most important devices with the locomotive control system.

a)

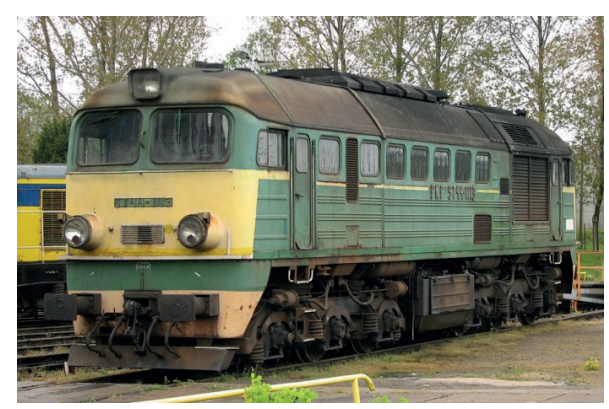

b)

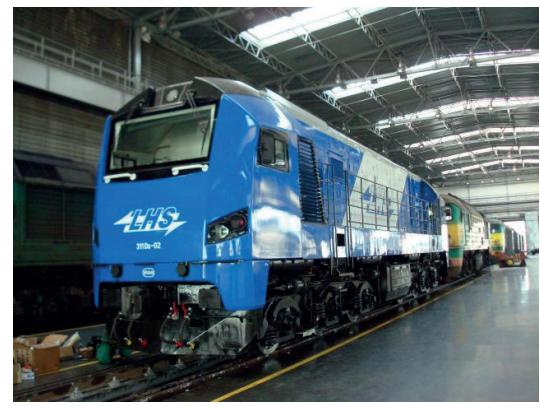

Figure 1. View of the ST44 series locomotive: a) before modernization, b) after modernization

Source: NEWAG S.A.

The propulsion system is a 12-cylinder four-stroke IC engine with the designation 7FDL12 EFI, equipped with electronic fuel injection. The modernized locomotive is equipped with two modified driver's cabins equipped with an altered control panel and a diagnostic information display. The locomotive was equipped with the new "Oerlikon" braking system. As a result of the modernization, the first locomotive was built on the Polish and European market, built on the basis of the integrated General Electric power unit, meeting current emission standards.

\section{Life cycle cost analysis}

In the first stage of the assessment of the modernization efficiency of the ST44 locomotive, the life cycle cost analysis (LCC analysis) was used. The analysis was carried out using a 6-step procedure, described in detail in the work ${ }^{5}$, taking into account the requirements of the international standard PN-EN 60300-3-3 Reliability management. Application Guide - Estimating the Life Cycle Cost. As a measure of effectiveness, the lifecycle cost (LCC) calculated in the 25-year operational period of the locomotive was adopted.

\subsection{Initial assumptions}

The assumption was made that the analysis is of a comparative nature, consisting in comparing the economic effects obtained in locomotive exploitation before modernization with the effects obtained after its modernization. In the first stage

5 M. Szkoda, Kształtowanie potencjału przewozowego przedsiębiorstw transportu kolejowego, Monograph, Cracow University of Technology Publisher, Cracow 2017. 
of the analysis, a set of input data was developed for both the unmodified and modernized locomotive. In the case of an unmodified locomotive, it was necessary to determine:

- load distribution of the drive system for the actual operating conditions;

- actual fuel and engine oil consumption;

- working time, mileage, transport performance during the year;

- periodicity, labor consumption and costs of preventive maintenance resulting from the maintenance cycle;

- reliability indicators RAMS (Reliability, Availability, Maintainability, Safety).

Based on the operational data of the ST44 locomotive park operated by the railway carrier, the load schedule of the internal combustion engine was determined and the following operational indicators were determined:

- average annual mileage of the locomotive: 118000.0 [km/year];

- average working time of the locomotive: 5200.0 [hour/hour];

- average transport work: 179000.0 [thousand btkm/year].

\subsection{The LCC model}

Due to the comparative nature of the analysis, a common cost model was developed for the adopted variants, in which the LCC was expressed in the following formula:

$L C C=\sum_{t=1}^{T}\left[\left(K N_{t}+K E_{t}\right) \cdot \frac{1}{(1+i)^{t}}\right]=\sum_{t=1}^{T}\left[\left(K N_{t}+K U P_{t}+K U B_{t}+K B G_{t}+K Z P_{t}+K Z O_{t}\right) \cdot \frac{1}{(1+i)^{t}}\right]$,

where:

$K N_{t}$ - acquisition costs in year $t$,

$K E_{t}$ - operating costs in year $t$,

$K U P_{t}-$ costs of preventive maintenance in year $t$,

$\mathrm{KUB}_{t}$ - corrective maintenance costs in year $t$,

$K B G_{t}$ - costs of unavailability in year $t$,

$K Z P_{+}$- fuel consumption costs in year $t$,

$\mathrm{KZO}_{t}$ - costs of engine oil consumption in year $t$,

$i$-discount rate,

$t$ - another year in the cycle of the locomotive's existence,

$T$ - assumed operating time of the locomotive.

The acquisition costs of the $\mathrm{KN}$ in the base variant (variant ST44 14D40) constitute the maintenance costs of P5 (main repair). For the modernized ST44 locomotive (ST44 GE variant), the acquisition costs are total expenditures for modernization, taking into account, among others: costs of documentation, costs of commissioning, purchase and delivery costs of the internal combustion engine, costs of necessary components and elements, and labor costs. It was assumed that the modernization of the locomotive will be carried out as part of repairing the maintenance level P5. The KE operating costs are costs related to the operation of the locomotive, i.e. maintenance and use. They are costs of fuel consumption, engine oil, corrective maintenance, preventive maintenance and others. 
In the applied model, 12 cost elements were defined using 28 parameters and functions. The cost elements were estimated using the engineering method of cost estimation ${ }^{6}$. The LCC analysis was performed on undiscounted and discounted costs (discount rate $i=5 \%$ in line with EU recommendations for the assessment of investment projects in rail transport).

One of the cost elements was the corrective maintenance costs (KUB) related to the repair of the current locomotive. These costs include labor costs (KUBR) as well as costs of materials and spare parts (KUBM). The corrective maintenance costs on an annual basis were expressed in the following formula:

$$
\mathrm{KUB}_{t}=K U B P_{t}+K U B M_{t}=M N F \cdot\left[\left(M_{\mathrm{B}} \mathrm{H}_{B} \cdot C P H_{B}\right)+A C M_{B}\right],
$$

where:

$M M H_{B}$ - average labor consumption of current repair,

$\mathrm{CPH}_{\mathrm{B}}$ - cost of man-hour for the current repair,

$A C M_{B}$ - cost of materials used in the current repair,

$M N F$ - mean number of locomotive failures in the year of operation:

$$
M N F=\frac{T Z}{M T B F},
$$

where:

$T Z$ - average working time of a locomotive in a calendar year in [hour/year],

$M T B F$ - mean time between failures in [hours].

Preventive maintenance costs (KUP) are expenditures for repairs and periodic inspections resulting from the maintenance plan for the locomotive.

The costs of unavailability (KBG) are the sum of costs resulting from the locomotive being in a condition that makes it impossible to perform the tasks planned for implementation. The costs of unavailability include, for example: costs of contractual penalties, costs of guarantees, costs of lost opportunities and others. In the calculation formula for $\mathrm{KBG}$, the technical readiness index designated as part of the reliability analysis is used.

The costs of diesel oil consumption (KZP) and engine oil (KZO) were calculated on the basis of actual operational data collected by the carrier and using the characteristics of the new 7FDL12 EFI type internal combustion engine. The advanced method used in the LCC analysis to calculate the fuel consumption of diesel locomotives is the use of a mathematical model of operating conditions of the power unit: engine - generator together with a simulation model, allowing to map the actual operating conditions of the locomotive. This approach is presented in the paper?

\subsection{The analysis of the cost model and final results}

The analysis of life cycle costs according to the developed model showed that the proposed variant of modernization of the ST44 locomotive based

PN-EN 60300-3-3:2017-07 - Reliability management. Application Guide - Estimating the Life Cycle Cost.

7 M. Babel, M. Szkoda, Diesel locomotive efficiency and reliability improvement as a result of power unit load control system modernization, Eksploatacja i Niezawodność - Maintenance and Reliability 2016, 18(1), p. 38-49. 
on the integrated drive unit of General Electric is economically justified. The calculations performed using the CATLOC software show that the modernization of the locomotive provides very high savings in LCC costs - nearly PLN 11.3 million, i.e. $19.8 \%$ less compared to an unmodified locomotive. The comparison of total costs in the 25-year period after modernization for the analyzed variants is presented in Figure 2a. Significant savings are obtained in the operating costs of the modernized locomotive. These costs are $27.2 \%$ lower compared to an unmodified locomotive (Figure 2b).

a)

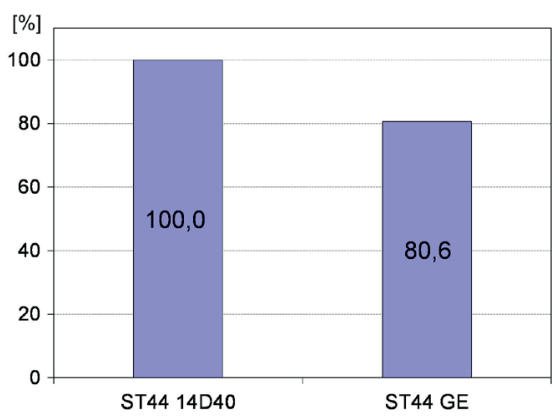

b)

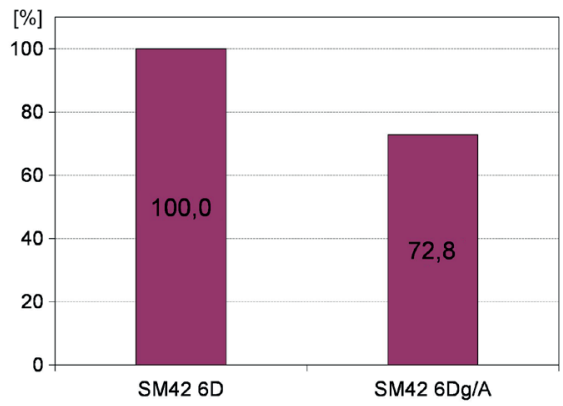

Figure 2. Comparison of the costs of the analyzed variants: a) LCC total costs, b) KE costs of exploitation

Source: own elaboration

For the unmodified ST44 locomotive, the dominant costs are fuel consumption costs (KZP) $72.1 \%$ and costs of unavailability (KBG) $12.0 \%$. Preventative maintenance costs (KUP) constitute $8.9 \%$ of total costs (Figure 3a).

For the modernized ST44 GE locomotive, a significant reduction in the costs generated in the life cycle was obtained thanks to increased reliability, readiness and availability of spare parts. This results in a significant reduction of expenditures for corrective maintenance and lower costs of preventive maintenance of the vehicle (inspections, periodic repairs). The costs of preventive maintenance (KUP) and corrective maintenance (KUB) of the modernized locomotive account for $9.4 \%$ of total costs.

The largest share in LCC is fuel costs (KZP) 69.5\% (Figure 3b).

The largest savings compared to the non-modernized locomotive concern the costs of diesel oil consumption and engine oil costs. The calculations, confirmed by supervised operation, showed that fuel savings amount to $22.2 \%$ on average and $62.3 \%$ in engine oil consumption. Considering the probability of fuel price increases, this is of great importance in long-term planning.

The analysis showed that the modernization of the ST44 diesel locomotive based on the integrated General Electric power unit provides significant savings in operating costs compared to the unmodified locomotive. Table 1 presents the average 
level of savings in annual terms for selected categories of costs of the modernized ST44 locomotive.

a)

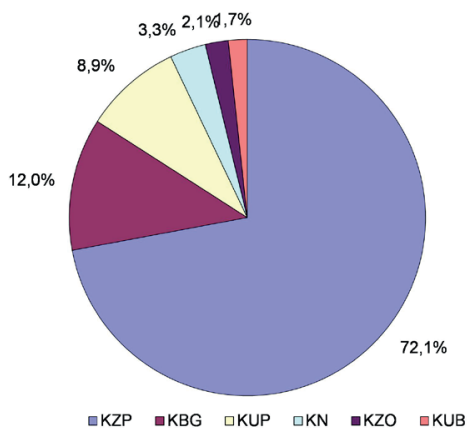

b)

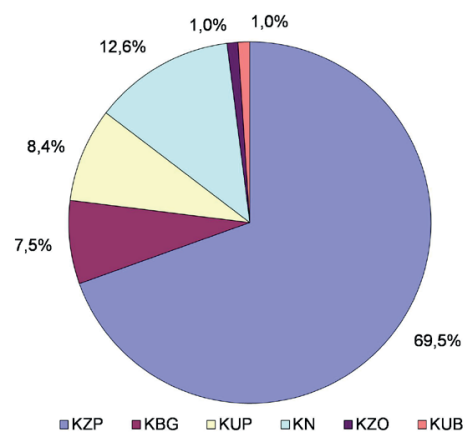

Figure 3. Structure of LCC costs of the analyzed variants: a) variant ST44 14D40, b) variant ST44 GE

KZP - fuel consumption costs, KUP - preventive maintenance costs, KN - purchase costs, KUB corrective maintenance costs, KBG - unavailability costs, $\mathrm{KZO}$ - motor oil consumption costs Source: own elaboration

Table 1. Average annual savings for the ST44 GE locomotive

\begin{tabular}{|l|c|c|c|c|c|c|}
\hline \multicolumn{2}{|c|}{ Cost category } & KUP & KUB & KZP & KZO & KBG \\
\hline \multirow{2}{*}{ Savings } & $\%$ & 22.9 & 50.8 & 22.2 & 62.3 & 50.0 \\
\cline { 2 - 7 } & PLN/year & 58899.3 & 25263.7 & 456618.6 & 37861.4 & 174762.0 \\
\hline
\end{tabular}

Source: own elaboration

\section{The cost-benefit analysis}

In the next stage of the assessment of the efficiency of the modernization of the ST44 locomotive, a cost-benefit analysis was carried out. The cost-benefit analysis is simply a reduction of the assumed future costs and benefits from the modernization of the locomotive to current values, taking into account the change in the value of money over time. The purpose of the analysis is to provide information on whether the modernization of the locomotive provides appropriate benefits adequate to the costs of modernization.

The analysis was carried out in accordance with the recommendations of UNIDO - the United Nations Organization for Industrial Development. The analysis includes all data developed for the needs of LCC calculations and was supplemented with additional assumptions, such as investment financing costs, depreciation costs, tax charges, operating revenues and other. As a result of the analysis using the UNIDO Comfar III Expert software, the following values of indicators characterizing the efficiency level of the locomotive modernization were determined: 
- updated Net Present Value, NPV = PLN 3924 413.3;

- Internal Rate of Return, IRR = $14.62 \%$;

- Payback Period, PP $=7.4$ years;

- Discounted Payback Period, PP $=9.3$ years.

Based on the calculated indicators of the cost-benefit analysis, it was found that the analyzed version of the modernization of the ST44 locomotive shows economic justification, which confirms the correctness of its choice based on the LCC criterion. In addition, a sensitivity analysis was carried out for the analyzed option, aimed at determining the so-called limit expenditures, i.e. the maximum expenditure on the modernization of the locomotive. Taking into account all the assumptions from the LCC analysis and the requirements regarding the method of financing the project, the calculated safety margin due to capital expenditures is $86.5 \%$. With such an increase in the estimated expenditures for modernization, the economic effects obtained in the 25-year period of locomotive exploitation are comparable to the effects obtained for the locomotive before modernization.

\section{Conclusions}

The purpose of modernizing the ST44 diesel locomotive was to adapt it to the modern requirements of functional properties. The main areas of reconstruction and modernization concerned: a power unit with the engine with a limited level of exhaust emissions, microprocessor control of the engine-generator unit, improved cab ergonomics and driver's work stations, economic drive of machines and auxiliary equipment and improvement of braking system components.

The level of error committed in the analysis of the efficiency of locomotive modernization depends on the stage of its implementation and the richness of the database available. The input database for the analysis and assessment of the modernization efficiency of the ST44 locomotive is based on the current costs of modernization, preventive and corrective maintenance costs as well as diesel and motor oil prices. The analysis also uses actual data on fuel consumption by non-modernized locomotives, which are important in the calculation of LCC. The conducted efficiency assessment showed that the modernization of the ST44 diesel locomotive provides significant savings in operating costs in relation to the non-modernized locomotive. In the period of 25 years of use, the savings may amount to approximately PLN 11.3 million, i.e. 19.4\% LCC for one locomotive. The comprehensive, complex assessment of effectiveness in the concept and design phase was the basis for the railway undertaking's decision to modernize the first batch of 30 ST44 locomotives.

\section{References}

Announcement of the Minister of Infrastructure and Construction of 27 January 2016, regarding the publication of a uniform text of the Regulation of the Minister of Infrastructure on general technical conditions for the operation of railway vehicles (Journal of Laws of 2016, item 226). 
Babeł M., Szkoda M., Diesel locomotive efficiency and reliability improvement as a result of power unit load control system modernization, Eksploatacja i Niezawodność - Maintenance and Reliability 2016, 18(1), p. 38-49.

Evaluation of the modernization efficiency of ST44 series locomotives based on current operational data. Paper No. M-8/14/2010/6, Cracow University of Technology, Institute of Rail Vehicles, Krakow, May 2010.

Evaluation of the efficiency of supplementing the number of diesel locomotives in the enterprise PKP LHS Sp. z o.o. Paper No. M-8/306/2017/P, Cracow University of Technology, Institute of Rail Vehicles, Cracow, May 2017.

PN-EN 60300-3-3:2017-07 - Reliability management. Application Guide - Estimating the Life Cycle Cost.

Strategy of renewal of the locomotive park in the enterprise of PKP LHS Sp. z o. o. Paper No. M8/599/2007, Cracow University of Technology, Institute of Rail Vehicles, November 2007.

Szkoda M., Kształtowanie potencjału przewozowego przedsiębiorstw transportu kolejowego, Monograph, Cracow University of Technology Publisher, Cracow 2017.

Tułecki A., Ekonomiczno-techniczne aspekty odnowy parku spalinowych pojazdów trakcyjnych, Czasopismo Techniczne 2003, 3-M.

\section{Corresponding authors}

Magdalena Satora can be contacted at: magdalena.satora1@gmail.com

Maciej Szkoda can be contacted at: maciej.szkoda@mech.pk.edu.pl 